\title{
Accounting as a tool of state ideology to control captive workers from a House of Correction $^{1}$
}

\author{
Silva, Adriana; Rodrigues, Lúcia; Sangster, Alan
}

\begin{abstract}
Purpose -This paper seeks to interpret the use of accounting information relating to the House of Correction, a public safety institution established in Rio de Janeiro for the control of workers under a tutelage system (1831-1864). The aim of the House of Correction was to develop a disciplined workforce of former slaves and other 'Free Africans'. Various control and information procedures were put in place to monitor its achievement of this goal.

Design/methodology/approach - This study is based on historical archival research, mainly conducted at the National Archive of Rio de Janeiro and at the Brazilian National Library. The study uses Althusser's ideology concept and the Marxist concept of reproduction of labour to show how accounting information enabled the administrator of the House of Correction to exercise control over the 'Free Africans' consistent with the ideologies of the period and place.

Findings - We find that the House of Correction pursued a policy of ensuring 'Free Africans' were docile, obedient and familiar with State ideology.

Research limitations/implications - The research is based on a single case study and it shows the need for both comparative and interdisciplinary analysis in order to increase an understanding of the use of accounting information in ancient prison contexts, as well as in contemporary situations.

Originality/value - This paper extends our knowledge of the use of accounting for the control of workers, who were either captive or repressed due to their ethnical differences; and it shows how ideology can be imposed through the use of accounting information. We extend theory by applying the Marxist and Althusserian concept of reproduction of labour to the case of 'Free Africans'.
\end{abstract}

Keywords: Accounting History, Reproduction of labour power, 'Free Africans', Rio de Janeiro's House of Correction, Brazil

Paper type: Research paper

\section{Introduction}

Accounting systems have an important role in the institutionalized subordination and control of labour (Macintosh and Quattrone, 2010). Companies, for example, use management accounting and control systems as a tool for the surveillance, discipline and control of their workforce (Hopper and Macintosh, 1993). Understanding the use of management accounting in the organizational context demands more than a technical description of the accounting information systems and it is important to know how these accounting systems interact with the organizational environment (Roberts and Scapens, 1985). This study responds to the research gap identified by Tyson et al. (2005) and Tyson and Fleischman (2006) concerning the relationship between accounting and the control of prison workers. It seeks to contribute towards research into accounting for the control of workers who were either captive or repressed due to their ethnical differences, and to critical accounting research on race and racial injustice.

${ }^{1}$ DOI 10.1108/AAAJ-04-2018-3444 
The focus of this paper is the $19^{\text {th }}$ century prison in Rio de Janeiro, the House of Correction (RJHC). Araújo (2009) presents the history of RJHC, describing the reasons why it was built, the way RJHC workers and convicts were treated, and details of the Brazilian Empire's prison system. His objective was to write the history of the first Brazilian prison that used forced labour as a means of coercion. He did not consider the manner in which accounting control was exercised. Accounting control techniques can work within a disciplinary matrix, for example, to regulate the individuals' behaviour (Chapman et al., 2009, Foucault, 2001). The objective of this paper is to understand the use of accounting information for the control of 'Free Africans' and how this control aimed to ensure the maintenance of this workforce under a slavery ideology.

This paper builds in Araújo's study by investigating the relationship between accounting and the control of captive labourers. 'Free Africans' were African slaves freed when the vessels transporting them to Brazil were intercepted by the British. This new social category of 'Free Africans' impacted both the control activities performed by the prison authorities and the relationships established within the prison (Araújo, 2009), changing both the control and working relationships in the spaces where slaves, convicts, poor free men and the military coexisted (Sousa, 1999). As will be demonstrated in this paper, because the colour of their skin made them visually indistinguishable from African slaves and because of continuing adherence to a slavery ideology in Brazil (Hall, 1985), 'Free Africans' were not treated as free workers of the RJHC, but were accorded the same status as slaves in the eyes of those who controlled them (Anonymous, 2019).

Due to its perceived importance, a wide range of administrative documents of the RJHC have been stored at the Rio de Janeiro National Archive and at the Brazilian National Library. The records of the Justice Series Fund (Fundo Série de Justiça) and the House of Correction's collection are the main sources used in this study, including those identified by Araújo (2009). Through analysis of the documents they contain, it was possible to identify many records that prove the existence of control measures applied to the 'Free Africans' who worked on the construction of the RJHC. This study contributes to the debate on the use of accounting for the control of captive labourers, showing how accounting helped to guarantee the maintenance of labour power aligning to the established ideology. It also contributes to critical accounting research on race and racial injustice (Annisette and Prasad, 2017), investigating the prevailing ideological context to understand (Annisette, 1999) the organization's behaviour in organising and controlling the 'Free Africans'.

In doing so, this paper brings new knowledge to previous research in similar contexts: Tyson et al. (2005) identified the accounting control procedures for the regulation of slave labour in the British West Indies plantations during the process of transition from slave labour to wage labour; and, Fleischman and Tyson (2000) showed how accounting was used to regulate labour in Hawaii's sugar plantations and identified that labour statistics were maintained on the basis of the workers' ethnic origins. We also invoke the concept of race by showing that the 'Free Africans' were radicalized by dominant groups in order to justify their exploitation and degradation; and in turn, as suggested by Annisette $(2009 ; 2017)$ in the context of critical accounting research, we make value judgments on the ideological context within which accounting practices are undertaken. Thus, this study addresses the gaps in the literature regarding the development of studies that can present the relationship between accounting and prison 
labour (Tyson and Fleischman, 2006; Tyson et al., 2005) and between accounting and race (Annisette, 2009; 2017).

Using the concept of slavery ideology, this paper examines the practices and the role of accounting information to control the 'Free Africans' in the construction of the RJHC in 19th century Brazil. It argues that the use of these accounting practices and information in the RJHC, as a means of facilitating the application of the disciplinary regime to the 'Free Africans', was intertwined with the State's idea that 'Free Africans', although 'free', should be subject to slavery. It analyses how the use of accounting information is influenced by the dominant class ideology and how it is intertwined with disciplinary regimes established to monitor the work done in an institution. And, it explores how the application of physical punishment and the distribution of resources were combined with disciplinary and monetary measures to maintain discipline in the RJHC, therefore expanding the concept of accounting for social control. It also extends theory by applying the Marxist concept of reproduction of labour to the case of 'Free Africans'. Thus, this research, besides being a pioneer regarding its development in a South American country, will also strengthen the limited existing literature in the field and will allow the results to be used as a means of comparison, regarding the use of accounting in an oppressive regime, with other realities.

This paper is organized as follows: the next section presents the economic, political and social context at the time; this is followed by a literature review on accounting for the control of labour and the theoretical framework focusing on ideology and reproduction of labour power. The research method is then presented, followed by a discussion of the nature and the role of accounting in the control of the RJHC's 'Free Africans'. Finally, the main conclusions are presented.

\section{Economic, Social and Political Context}

Following its political independence from Portugal in 1822, the Federal Republic of Brazil was organized as a single State, under a constitutional monarchy. The independence of Brazil presented a serious risk of civil war and maintaining slavery was viewed as crucial to secure the union between several groups (Koerner, 2006). In response, the new Brazilian government sought to consolidate an alliance with regional political elites, public workers, land owners and tradesman, in which slavery relations were preserved (Sorj et al., 2008). However, Britain refused to recognize the new South American country unless the Brazilian authorities ended the transatlantic African slave trade (Bethell, 1970).

Brazilian independence brought the need for a political organization that could assure the country`s stability. A new constitution was adopted (Koerner, 2006). The Brazilian Empire's political constitution, confirmed by Emperor Dom Pedro I in 1824, highlighted a process of full integration of human rights. The bill of rights assured the sanctity of the right to freedom, equality, individual safety and ownership. This constitution also highlighted the principles of individual responsibility for legality and crimes committed. The previous regulatory process that allowed the State to terrorize common citizens (Holloway, 1993) through brutal punishments (such as floggings, torture, hot iron burns and other cruel punishments) was terminated. 
Title VIII of the 1824 Constitution foresaw the organization of a Civil and Criminal Code, based on the solid foundations of Justice and Equality (ANRJ, Constituição de 1824, art. 179, paragraph 18). It replaced the $5^{\text {th }}$ book of the Ordenações Filipinas of 1603, the Portuguese Penal Code, which had remained in force after Brazils independence in 1822. The Brazilian Empire's Criminal Code was enacted on 16 December 1830.

For Chazkel (2009), the Criminal Code was filled with 'vestiges of slavery'. For instance, it established sentences of death, imprisonment (simple or prison with work), assignment to galleys (where the convicts had iron chains and had to work on public works in the provinces), exile, banishment, expatriation, fines and the suspension or loss of public employment (ANRJ, Constituição de 1824 [1824 Constitution], Articles 33 to $64)$. In 1832, as a means of complementing the Criminal Code of 1830, the Code of Criminal Procedure came into force. It was based on Enlightenment doctrine concerning the right to punish. The Enlightenment doctrine emphasizes the modification of preexisting relationships that link the will, the authority and the use of reason (Foucault, 1984, p. 35), so as to afford individuals due respect (Norrie, 1991, p.2). Based on jusnaturalism and contractualism, the Enlightenment doctrine condemns the validity of unjust laws, imposed by coercion and force, and defends obedience to the laws that are derived from the consent of citizens (Praciano, 2007). To sum up, the Enlightenment doctrine preaches the defence of the dignity of man and his rights before the State.

To create a favourable environment for the enforcement of the penalties determined by the 1830 Criminal Code, the Brazilian prison system was influenced by the panoptic architectural style of Jeremy Bentham (Araújo, 2009), where a central observer could see all the places where there were prisoners, and by the Auburn system (Silva, 1997), which consisted of workshops, yards, and individual cells that provided silence.

\section{The Rio de Janeiro House of Correction}

To enhance Rio de Janeiro's public security system, in the early 19th century, the Portuguese authorities established an organized police force (Araújo, 2009). Town halls were responsible for the management of prisons. Housed on a two-storey building, built in one of the corners of the square, the jail in Rio de Janeiro was located on the lower end of the town hall building. Although they were located in the same building as the town hall, these prisons were more like deposits for human beings, unsafe and unsanitary, housing convicts, free men and women, slaves, 'Free Africans', vagabonds, the mentally insane, Native Americans, prostitutes and drunkards. The convicts were either put under surveillance or imprisoned in irons. When condemned to forced labour, they were sent to work in public works (Salla, 1999). The reform of the prison system embodied in the 1824 Constitution, gave more attention to security, cleanliness, and ventilation, as well the separation of convicts according to the nature and circumstances of their crimes. By 1830, Rio de Janeiro had more than 30 prisons: military, ecclesiastical, naval (temporary ship prisons where the convicts slept at night and worked during the day) and civil. The civil prisons included those in the Aljube, the Santa Barbara, the Ilha das Cobras and the Calabouço do Castelo (Karasch, 2000, pp. 176-178; Koerner, 2006, p. 210).

The Ministry of Justice was responsible for the reform of the existing prisons and the construction of new ones using the labour of 'Free Africans' and poor convicts from 
the Rio de Janeiro province (Araújo, 2009). In 1831, the Society for the National Independence and Freedom of Rio de Janeiro presented a plan for a House of Correction and Labour, with the purpose of improving the control methods of poor, slaves and 'Free Africans' (Araújo, 2009). This new institution was created based on the Constitution of 1824 and the Criminal Code of 1830.

Initially, it sought to coerce a class of rebels that had been participating in constant uprisings against the politics of the end of the first reign (when Emperor Dom Pedro I ruled Brazil, 1822-1831). In 1832, construction of the RJHC started and, in 1834, sixty convicts began working on the project (CRL, Relatório da Repartição dos Negócios da Justiça [Report of the Bureau of Justice], 1834). Changing the concept of penal confinement, various categories of people were used besides the convicts, including 'Free Africans', slaves, free workers (such as artisans and masters), as well as those considered to be 'idle or troublemakers' (Araújo, 2009, p. 1).

The different classes of individuals that took part in the construction of the RJHC, presented an extraordinary set of challenges for the managers. The first step taken regarding an administrative organization was the creation of the Inspecting Committee for the construction of the House of Correction (ANRJ, Fundo Série Justiça (Justice Series Fund), IIIJ7-138. Aviso do Ministro ao Inspetor das Obras da Casa [Notice from the Minister to the Inspector of the Works of the House], pp. 27-29). The Committee was composed of three citizens nominated by the Government: an Engineer who would be responsible for managing the construction, a Treasurer and an Administrator.

According to article 3 of the Committee regulation, its responsibility was:

1. To manage and control the revenues and expenses pertaining to the construction, to inspect the collection of its funds and accounting;

2. To set the bookkeeping methods that should be followed by the treasurer, the bookkeepers, and the collector;

3. To follow and make sure that all superior orders sent by the State Office for Justice Affairs are followed and provide all the requested information;

4. To order the payment of the monthly wages and of any kind of expenses;

5. To open and close all accounting ledgers and registrations.

The construction and maintenance of the RJHC depended on public funding, therefore the Inspecting Committee had to report to the Ministry of Finance. It did so by preparing accounting reports on the construction of the House of Correction.

\section{The 'Free Africans' in public institutions}

Between 1831 and 1850, several ships were apprehended for illegal trading in slaves (Araújo, 2009), resulting in the freeing of several Africans, i.e. 'Free Africans'. In 1840, about 40,000 Africans illegally entered the Rio de Janeiro and São Paulo Provinces but this number was not reflected in the official records of the number of 'Free Africans' in Brazil (Anonymous, 2019). According to a report issued in 1867 by the Ministry of Justice only 10,719 'Free Africans' were registered in Brazil between 1821 and 1851, (Center for Research Libraries [CRL], Relatório do Ministério da Justiça [Report of the Ministry of Justice], 1867, p. 16; Anonymous, 2019). 
Keeping the peace became a main concern with the country's elite. This concern was justified by a view that the liberation of 'Free Africans' was likely to lead to revolts among the Africans who were still captive. In order to address this problem, and also with the justification that they needed to adapt with local customs to become free, the 'Free Africans' were distributed among public works and rented to private entities for compulsory work (Sousa, 1999; Mamigonian, 2002; Moreira, 2005; Araújo, 2009; Anonymous, 2019).

A 'tutelage' system was established, defining a period of 14 years to educate the 'Free Africans' before they could be liberated. A Curator was part of that system, responsible for monitoring movements of the 'Free Africans' and reporting to the Surrogate Judge/Ministry of Justice (Anonymous, 2019). The Curator kept a book called the 'Register of Emancipated Negroes' in which was recorded the name, age, body marks, family, nation, and the name of the vessel in which each 'Free African' was captured (FO-286, p. 14). During the tutelage period, the Curator was responsible for assisting the 'Free Africans', and reporting data relating to them to the Surrogate Judge/Ministry of Justice including, for example, a list of people who have hired the services of 'Free Africans'; a list of debtor hirers; and a list of 'Free Africans' who had died.

The Curator decided how the 'Free Africans' would be distributed, and he was informed of the total number of 'Free Africans' who were ill, and/or dead under private or public possession. 'Free Africans' could refer all of their complaints to the Curator. All the information collected by the Curator was recorded in detail and forwarded to the Ministry of Justice and discussed, subsequently, by the Brazilian and British Governments. The Curator role was comparable to that of the Special Magistrates that served the British Colonies during the equivalent 'apprenticeship' era (1834-1838) (Tyson et al., 2005).

The procedures of hiring and auctioning represented the way in which the social insertion of those 'Free Africans' was achieved: the 'Free Africans' were paraded in public squares and auctioned to private individuals who offered to rent their services (Florence, 2002). However, Notice 612 of the Ministry of Justice on December 1, 1837, revealed that the 'Free Africans' exhibited in the public squares were selected from those who remained after the healthiest and most robust were assigned to work in the public sector.

According to the Instructions of October 29, 1834, the auctioning of 'Free Africans' to private individuals was done under contract. Under the terms of this contract, it was established that they would pay rent for 'Free Africans' and support and care them. The rent was to be paid to the Curator and delivered, by him, to the Auction Judge from the Ministry of Justice (Bertin, 2009; Anonymous, 2019). 'Free Africans' working for the public sector received small bonuses that they could spend as they wished, such as on tobacco (Bertin, 2009; Mamigonian, 2017).

Besides maintaining the peace, the distribution of 'Free Africans' avoided the high expenses of sustaining them in the 'deposit'. This approach also provided the State with some additional revenue by exploiting their work: all public works had, in either a higher or lower quantity, work done by the 'Free Africans' (Araújo, 2009; Florence, 2002; Moreira, 2005; Sousa, 1999). The presence of 'Free Africans' during the period 
of the construction of the RJHC between 1834 and 1850 was crucial (Araújo, 2009). Without the work of the 'Free Africans', the State would have found it much more difficult to build this first custom-built Brazilian prison. The 'Free Africans' at the RJHC performed many roles, including those of masons, diggers, carpenters, bricklayers, and blacksmiths (Araújo, 2009).

Similarly to what was reported by Tyson et al. (2005), instead of providing economic incentives like market-based wages, the 'Free Africans' were subjected to: categorizations, established by the law of 1831, that legally differentiated them from slaves and free people. These included fines of three thousand reis if they walked down the street at night without the protection of a white man (Reis, 2008); and prison sentences or torture if they were not pursuing their activities as expected by their superiors. In addition, social controls were established by the tutelage system to avoid leaving the 'Free Africans' helpless or uncontrolled (Mamigonian, 2017). No 'Free African' was a slave, however, they were seen as slaves because 'Free Africans' were subject to the ruling slavery ideology (Anonymous, 2019).

Florence (2002) found that the 'Free Africans' were sent to the Santa Casas in Porto Alegre and Salvador, in addition to the RJHC; and highlighted the difference in the treatment given to 'Free Africans' meant for private use and 'Free Africans' meant for public entities. In the public sector, besides the amount paid to the state for the 'Free Africans' that were hired, a certain amount of money could also be paid to the 'Free Africans' themselves for their labour. For example, the 'Free Africans' of the Santa Casa in Salvador received weekly bonuses for their work, whereas the Africans destined for private use did not receive any financial rewards. Their owners only paid the State for their rental.

Moreira (2005) examined the 'Free Africans' in a specific workplace, belonging to the State, the Estrela's Gunpowder Factory (Fábrica de Pólvora da Estrela), in the Rio de Janeiro province, between 1831 and 1870. The 'Free Africans' sent to the Gunpowder Factory began by working in agriculture, with cattle, cleaning, cutting wood and even by doing some domestic services in some of the workers' homes. These activities were seen as a first 'stage' until some of them were deemed fit to perform other activities that demanded some technical training and care with explosives, at which point, they received some bonuses (ibid., p. 173).

The 'Free Africans' were encouraged towards acceptance of the tutelage system as protection. However, their acceptance was driven by constant coercion, and the slave dominance rule embedded within it. Some resisted, asking to be transferred to other jobs, requested improvements in their treatment, clothing, and food. Some even fled. Those who fled did so, almost always, for a few days, and sometimes to other establishments which they considered better places to be. This was likely because the 'Free Africans' were aware that if they were no longer under the protection of the government tutelage system, the possibility of their being absorbed into slavery was significant (Sousa, 1999; Mamigonian, 2002; 2017).

Sousa (1999) sought to identify how the 'Free Africans' realized they had rights and how they tried to turn emancipation ideologies into something real. He noted that some 'Free Africans' perceived insubordination as a key factor for the attainment of freedom. This was evident when their 14 years under the tutelage system ended but they were not 
liberated. In response, they tried to escape or behaved inappropriately in the hope of receiving their letters of emancipation. Their freedom was always monitored by the Brazilian government - even when they achieved their liberty after their period of tutelage ended, the Government never stopped monitoring them. Part of this process was the Government designating a place where 'Free Africans' should live and where they should work for a salary (Decree 1.303 of December 26, 1853). Any movement of the 'Free Africans' had to be notified to the Government. Records of this information were kept by the Government as a form of control of 'Free Africans' emancipation (Mamigonian, 2017).

Between 1835 and 1850, several other public institutions received the 'Free Africans' (Sousa, 1999). Among these were the São João of Ipanema's Iron Factory (Fábrica de Ferro São João de Ipanema); the Municipal Guard Corps (Corpo Municipal Permanente), the Navy and War's Arsenal (Arsenal da Marinha e da Guerra); the Court's Public Lighting (Iluminação Pública da Corte); the Baia's Shipping and Steamers (Navegação e Vapores da Bahia); the town hall (Câmara Municipal); the Military Colony of Itapura (Colonia Militar de Itapura); the Santa Casa da Misericórdia; the São Paulo road; the M. Grosso Mining Society (Sociedade Mineradora M. Grosso); the PE's Shipping and Steamers (Navegação e Vapores de $P E$ ); and the RJHC (Sousa, 1999).

In order to better describe the activities performed by the 'Free Africans' in public institutions, Sousa (1999) chose five of those institutions. His choice was based on the number of 'Free Africans' allocated to each institution: RJHC; São João of Ipanema's Iron Factory; the Estrela's Gunpowder Factory; The Navy and War's Arsenal; and the Military Colony of Itapura. The distribution of 'Free Africans' in public works was more advantageous to the Brazilian government compared to the value gained by renting slaves for the same purpose, due to the poor working conditions that resulted in high death rates. Because of these high death rates, the slave owners charged, on average, 800 réis per day to rent their slaves to work on public works, compared with 600 réis per day to maintain 'Free Africans' distributed among public works (ibid., p. 59).

The RJHC was one of the public institutions that most needed the 'Free African' workforce. The demand for them was so high that, in 1854, the RJHC's warden, António Falcão, advised the Ministry of Justice to reassign all the male 'Free Africans' who were rented privately (Sousa, 1999, p. 61). The elderly, women and children ended up, mostly, working for private contractors and in activities that did not demand too much physical effort.

In this paper, the RJHC has been selected for analysis on its use of accounting for the control of the 'Free Africans' so as to understand the reproduction of their workforce in a context of slavery labour. This choice was made due to the large number of 'Free Africans' there; and because it was the place where they were deposited upon arrival. Besides those measure already described, in order to adhere to the rules established by the prison system, management controls were necessary, including the establishment of a work discipline, and use of accounting as a tool capable of coordinating and guiding employee behaviour (Benston, 1963; Bryer, 2006; Caplan, 1966; Miller and O'Leary, 1987). 


\section{Literature Review and Theoretical Framework}

This section comprises of two subsections: the first reviews prior literature that addresses accounting for the control of labour; the second presents the theoretical framework used in this paper.

\section{Accounting for the control over labour}

Bryer (2006, p. 522) argues that accounting is not the only available technique for management control and that it does not allow us to understand and control every aspect of an organization's reality. Nevertheless, he argues that accounting is capable of providing an information system within which every other control system and reality are subsidiary and subservient. He concludes that accounting is one of the most important control systems in an organization, because it allows for the domination and regulation of worker behaviour.

Miller and O'Leary (1987) shed light on the construction of the individual as a more manageable and efficient entity. In their view, accounting techniques intertwined with others, internal and external to the company, seek to standardize and normalize the lives of individuals. The authors also state that accounting is important for the development of a series of techniques and calculating programs, that are used to regulate the way individuals work. For Miller and O'Leary, accounting is an organizational and social practice and is seen as being part of an important network of power relationships. Accounting is concerned with making all individual activities visible, bearing in mind its contribution to the effective functioning of society and the company (ibid., p. 240).

In environments that are measured by management actions, accounting techniques work as a normalizing vehicle necessary for the establishment of discipline in the workplace (Fleischman and Radcliff, 2005). The worker's motivation to achieve the company's set goals is one of the most important and concerning aspects in management (Benston, 1963). Benston presents accounting as an important tool in motivating workers. Managers can control basic activities and promote better performances from their workers through accounting. According to Caplan (1996), any viable information system is capable of supplying data on all, or at least a substantial part, of what happens inside and outside of a company. Accounting reports can provide information useful to be used as worker incentives, as well as to verify the fulfilment of the set goals in instances such as budget and production. On the other hand, when these goals are not met it may have certain negative consequences such as the dismissal of workers.

Whether in a captive or market-based environment, accounting has a role to play in labour systems work (Tyson and Fleischman, 2006). In a captive environment, Tyson and Fleischman (2006) record a scathing observation of accounting in the management of Japanese internment camps during WW2. Accounting reports were provided to monitor, management and socialise the captive population, as well to demonstrate that the captive population was maintained efficiently and cost effectively. That is, the accounting information worked as a tool to control the work process.

In the context of a slavery regime, Fleischman et al. (2011a) found that accounting had a role in disciplining the workforce. Periodic inventories were required by slave 
owners to track the whereabouts and condition of the workforce (Fleischman et al., 2004; Fleischman and Tyson, 2004; Fleischman et al., 2011a; Fleischman et al., 2011b). Accounting was used to measure the economic output of the plantation enterprise and to monitor labour turnout rather than efficiency (Tyson and Oldroyd, 2019). Similarly, in Trinidad and Tobago, Annisette (1999, p. 107) found that with the slave labour force as the major source of labour, there was no need to maintain records for the purpose of wage payments. Thus, the slave owners required an annual schedule specifying the increases and decreases of slaves, which were juxtaposed with the increases and decreases in livestock.

Race was habitually invoked as an ideology to exploit, appropriate, subjugate and dominate, or to resist attempts at such (Annisette, 2017, p. 9). The slavery logic codified the white bodies and the racialised bodies to develop sufficient differentiation between 'distinct human' and 'no distinct human' kinds (Annisette, 2017), that allowed the work's control and exploitation. According to Tyson and Oldroyd (2019), the accounting records were rarely used to measure efficiency, incentivize individual workers to increase their productive efforts, or reward them for achievements, but the accounting system was an essential element in the monitoring of slaves.

\section{Ideology and reproduction of labour power}

\section{Marx and the reproduction of labour power}

The concept of reproduction of labour power was originated in Marx and Engels (1969). According to Marx (1971), wages are the part of commodities with which the capitalist buys for himself a specific amount of productive labour power. Labour power is considered as a commodity that its possessor, the worker, sells to the capital in order to live. The cost of production of labour power is the cost required to maintain the worker as a worker and develop him into a worker. The shorter the period of training, the smaller is the cost of production of the worker, and the lower is the price of his wages (Marx, 1971). The cost of production of simple labour power, therefore, amounts to the cost of existence and reproduction of the worker. Wages so determined are called the wage minimum (Marx, 1971). Marx determines of the cost of production of labour on the basis of the quantity of commodities - food, clothing, housing, fuel - that would be necessary to maintain the health, life, and strength of a worker (Glenn, 1992).

The slave did not sell his labour power to the slave owner. The slave, together with his labour power, is sold once and for all to his owner (Marx, 1971). In a slavery society, slaves were seen as commodities (Rodrigues and Craig, 2018) that only need the minimum amount of food and clothing to keep them alive and capable of working. The amount necessary for the reproduction of labour power is determined by the needs of a historical minimum to keep the slave alive, that is, no wage was paid. It means that the slaves were not paid by their work, but what was expended was only what was necessary to keep them working (Blackburn, 1998). The slaves fed into the production side of the economic equation, but they consumed almost nothing. They could eat, but they could not build, except when ordered to, and never for themselves or their loved ones (Bales, 2007). If the slaves became free of the bondage, they do not have any food or any kind of support, without which they risked starvation.

The Althusserian concept of ideology and of the reproduction of labour power 
Following Marx, Althusser (1971) argues that the wage in a capitalist society is characterized as the amount to be paid that ensures that the worker has all the necessary conditions to be ready to work the next day. When hardly any period of apprenticeship is required, the cost necessary for his production is almost confined to the commodities necessary to keep the worker alive and capable of working. Thus, in this case, the wage is determined by the price of the necessary means of subsistence. As argued by Althusser (1971), the minimum historical amount that the ruling class needs to ensure the reproduction of labour power is not only that the labour power has the material conditions for its reproduction, but also that it is 'competent', in other words, that it is capable of working in a complex production process system. Thus, the wage earner should only receive the amount that permits him to present at the factory gate, and what is necessary for raising and educating the children in whom the proletarian reproduces himself. The children should not only learn techniques and knowledge but also the rules of good behaviour: the rules of morality, of respect for the socio-technical division of labour and of the order established by class domination. Thus, the reproduction of labour power needs not only the reproduction of its 'skills' but also its subjection to the ruling ideology (Althusser, 1971).

Ideology has a material existence in the apparatuses of State: ideological state apparatuses (ISAs) (families, schools, newspapers, church, legal requirements, political system), and the repressive state apparatus (RSA) (prisons, courts, army) (Rodrigues and Craig, 2009). Althusser (1971) distinguishes the ISAs from the RSA by the following basic difference: the RSA functions predominantly by violence, while the ISAs function predominantly by ideology. The use of the RSA is essential to secure by force (physical or other) the political conditions of the reproduction of relations of production or of the relations of exploitation.

In Brazil, policy makers were influenced by the ideology of slavery (Rodrigues and Craig, 2018). In this paper, we argue that 'free' labour is not always wage labour. In the case of 'Free Africans', although they were labelled as 'Free', the cost of the reproduction of labour power was similar to that of slaves. In the Brazilian slavery society, 'Free Africans' were seen as slaves, and the minimum amount that the ruling class imposed was almost the same as that which was paid to slaves: food, clothes, an occupation and the rules of good behaviour that were imposed using the state repressive apparatus. The wages paid to 'Free Africans' who worked at the RJHC (20 reis per day) was symbolic and it was withheld when they did not comply with the rules of good behaviour.

As argued by Althusser (1971), the reproduction of labour power requires skilled labour and, also, the reproduction of its submission to the rules of good behaviour. In the RJHC, besides acquiring the 'know how', the 'Free Africans' had to learn it in such a way as to ensure their subjection to the ruling slavery ideology (as suggested by the tutelage system). Through the RJHC, the State was a machine of repression for the 'Free Africans', enabling their surplus-value extortion (Althusser, 1971). The RJHC was part of the State apparatus, a force of repressive execution in the interest of the State and of the slave owners.

\section{Research Method}


Considering the objective to understand the use of accounting information for the control of 'Free Africans' and to ensure the reproduction of their workforce in a context of slavery ideology, in this paper we propose to answer the following research question: How was accounting information used in the monitoring of 'Free Africans' in the construction of the RJHC, within the context of a slavery ideology?

To answer the research question, a historical archival approach was used. To build a stronger analysis on the experience of 'Free Africans' at the RJHC, several archival materials were considered. The primary sources used in this study consist of the documents, notes, accounting records, legislation from the RJHC (1831-1861) and report about RJHC building (1834) maintained and held by the National Archive (AN), and the Digital Library of the Chamber of Deputies (BDCD), and the Center Research Library (CRL), together with the manifest written by the convicts and the 'Free Africans' which was sent to the Emperor (1841) held in the National Library (BN). Those sources were provided by the authorities involved in the management of the RJHC, by the State and by the convicts and the 'Free Africans'. The goal of considering several archival materials was to get various perceptions on the management of 'Free Africans', that is, to avoid possible biases in the sources.

The records of the RJHC included: notes (1839-1840), purchase documents and receipts (1839-1840), hired workers' salaries versus 'Free Africans' salaries report (1839 - 1840), a map (i.e. table) of wages paid to 'Free Africans' (1834 - 1838), distribution of 'Free Africans' from the House of Correction report (1851), letters sent from RJHC administrator to Ministry of Justice (1834 - 1848; 1849 - 1851; 1855 1858 ), and tabulated expenditure of workers and hired workers on the construction of the RJHC (1839-1840). BDCD and the CRL records examined included: RJHC regulation (1850) and the Ministry Justice report (1834). The record of the BN included the manifest written by the convicts and the 'Free Africans' which was sent to the Emperor (1841). This manifest presents their opinion on their treatment and the rightful usage of resources that were meant for them.

This research theme was chosen after visiting the National Archive in Rio de Janeiro and discovering archival material on the 'Free Africans' in the RJHC. The materials present a structure that demonstrates control over these individuals. Reading the study developed by Araújo (2009) on the RJHC and the 'Free Africans' who were deposited and worked there along with previous literature on the topic (Tyson et al., 2005; Tyson and Fleischman, 2006; Tyson and Oldroyd, 2019; Annisette 2009, 2017; Annisette and Prasad, 2017), provided the background and motivation to study the relationship between accounting and the control of prison workers at RJHC. All available research materials on 'Free Africans' in RJHC were photographed over an eight-month period. After analysing the more than 10,000 photos, a list of potentially relevant information was constructed. These materials were summarised to form the basis for this research. Analysis was based on the sources provided by the authorities involved in the management of the RJHC between 1831 and 1861, triangulated with the other sources to improve reliability.

An interpretative approach is adopted in this study of accounting practices within RJHC. This approach assists in describing, analysing and inferring the meanings of events. Locating the analysis within the specific context in which the object of the research emerges and operates, we emphasize the role of ideology as a set of practices 
and institutions that sustain an individual's imaginary relationship to his or her material conditions of existence (Althusser, 1971). In Brazilian society, the ruling class viewed 'Free Africans' as slaves. Although they should be considered free and should earn a salary when they learned a job, the State paid only the minimum that was necessary to keep they alive and ensure that they would be able to work the next day.

\section{The role of accounting information in the monitoring of 'Free Africans' in the construction of the RJHC, in a context of slavery ideology}

This section is divided into two parts: firstly, we show how the 'Free Africans' social category was located in a context of slavery ideology; and secondly, we show how accounting contributed to supply an information system within which every 'Free African' could be controlled according to the rules of the dominant class.

\section{How the 'Free Africans' social category was involved in a context of slavery ideology}

No 'Free African' was either a slave, or a convict. However, that was how they were treated. While, by definition, slaves and convicts have no freedom (because the first belonged to slave owners and the latter should be in jail working to complete a sentence), 'Free Africans' were required to work so that they might learn how to behave in Brazilian society upon gaining their freedom from the tutelage system. However, their unclear situation in a slavery society facilitated the exploitation of their labour. This was because, while they were denominated as 'free' labour, the tutelage system did not establish that a wage should be paid to them. Consequently, the initial need of workers for the construction of the RJHC was met by the 'Free Africans', who played an important role in giving this construction project momentum. From its inception, the RJHC served as a permanent home for the 'Free Africans' (Conrad, 1973). The 'Free Africans' were temporarily housed in the RJHC until they were rented or, as previously mentioned, assigned to the State's public works (Karasch, 2000; Salla, 1999), or to some other public organizations.

\section{$<$ Insert Table 1 here $>$}

Table 1 shows how 'Free Africans' deposited in the RJHC in 1851 were distributed. More information can be found in the cited document, which includes descriptions given to 'Free Africans', characterising them by groups according to some common characteristics, i.e. the name of the ship that carried them or the place where they disembarked in Brazil. In each of the columns of Table 1, we can see the places where the 'Free Africans' were sent after being 'deposited' at the RJHC. In summary, a total of 585 'Free Africans', from five different ships, were redistributed from the RJHC among seven different institutions with the intention of their learning a job.

The quality of treatment of the slaves and of the 'Free Africans' was extremely poor (Conrad, 1973; Karasch, 2000). The 'Free Africans' were subject to a military discipline (Araújo, 2009; Mamigonian, 2002). For any type of change of space, the 'Free Africans' needed special authorization; and, in any issues regarding disobedience, they were punished by their superiors (Mamigonian, 2002). Tyson et al. (2005) argues that in the 19th century the objective of prisons was to turn idle people into 'reliable and diligent workers' through their submission to a regular work habit and rigorous social control. The RJHC's regulations embraced this objective. In Article 31 of its 
constitution, it states that 'all prisoners will be forced to learn a job of those available at the RJHC' (BDCD. Decree 678, 6 July 1850, pp. 31-62). As will be shown later, this was also the case for 'Free Africans'.

Althusser argues that it is indispensable for 'the labour power to pay for housing, food and clothing, in short to enable the wage-earner to present himself again at the factory gate the next day' and the minimum required to keep slaves alive, where no wage was paid, is determined by the needs of the working class (Althusser, 1971, p. 131), that is, clothing and food. One characteristic of slave-based societies is that the reproduction of the skills of labour power tends to be provided within production itself (Althusser, 1971, p. 132). However, in a Manifesto sent to the Emperor by the convicts and the 'Free Africans' in 1841, there is a complaint about the quality of the food and the clothes they received (BN. Manuscritos [Manuscripts], II - 34, 25, 11):

\footnotetext{
...how many tears are shed by those poor men at those tables. They come at noon tired from working, sit at the table to feed their hunger, however, Imperial Lord, it is with hurt and sorrow that these miserable souls discover, when looking inside their bowl, the (rotten?) poison that lies within, suddenly they falter, become dispirited, and their hearts lie at their feet, and tears run down...

... at the House of Correction, we are given a pair of pants, a poor cotton shirt to be worn for the next three months, however my Lord, no matter how much good care we take of it, it won't last us over a month due to its terrible low quality...
}

Assuming the veracity of these claims, it is apparent that the State spent the minimum amount to enable the 'Free African' to present himself to work again at the RJHC the next day and be competent to work, in this case in the process of RJHC's building.

To subject the 'Free Africans' to the rules of the established order, accounting was used to supply an information system within which every 'Free African' was controlled.

\section{Accounting information used to control 'Free Africans' based on the rules of the dominant class}

The Inspecting Committee of the RJHC sent a monthly report to the Ministry of Finance regarding the construction works at the RJHC and its expenses. The accounting report was made through the presentation of several financial statements created for this purpose; and through proof of payment by the suppliers. The monitoring of the wages of the RJHC's workers was separated into two reports: 'Hired employee salaries' and "Salaries granted to 'Free Africans'".

Monitoring reports were prepared monthly. The reports regarding the wages of 'Free Africans' distinguish between their jobs, names, nation, total number of days worked, value of daily wage, value of monthly wage and the total amount paid for all 'Free Africans' at the RJHC's construction (ANRJ, Fundo Série Justiça [Justice Series Fund]. IJ7-20; Feria Concedida aos 'Africanos Livres' da Casa de Correção [Wage granted to the 'Free Africans' of the House of Correction]. It is clear, as was evidenced in the study by Carmona et al. (1997) on the Real Fábrica de Tabaco, that at the RJHC a setting was also created in which management could compare, differentiate, rank, homogenise, ${ }^{2}$ and even exclude individuals. The ideology had the function of classifying a population into

\footnotetext{
${ }^{2}$ That is, treating in the same way those who were considered similar.
} 
categories (Annisette, 2017; Hall, 1985): hired free workers and 'Free Africans'. As argued by Althusser (1971), when a period of apprenticeship is required, the cost necessary for labour work production is greater. Thus, there were also differences between the wages for technical jobs, and simpler jobs, both for external workers and 'Free Africans'. These reports state that 'Free Africans' with a defined job, received 20 reis a day, and the 'Free Africans' that worked as servants, received 10 reis a day. This evidence is presented in Table 2:

\section{$<$ Insert Table 2 here $>$}

An Official Letter to the Empire's Minister sent by the RJHC's Administrator in June 1857, states - '...external workers cost, at least, fifty percent more than Africans...' (ANRJ, Fundo Série Justiça [Justice Series Fund]. IJ7-13; Letter of 27 June 1857). This statement is consistent with monitoring reports made in 1839 and, in some respects, appears to be a considerable understatement. For instance, as shown in Table 2 , masonry work done by hired workers received daily wages of 640 reis, whereas the same job done by 'Free Africans' cost 20 reis a day (ANRJ, Fundo Série Justiça [Justice Series Fund]. IJ7-21; Feria Concedida aos 'Africanos Livres' da Casa de Correção [wage granted to the 'Free Africans' of the House of Correction].

However, the differences in wages cannot be taken at face value. Besides paying the 'Free Africans' 'wages', the Government also bore their basic expenses regarding food, clothing and health care. Therefore, in order to really understand the difference between the wages paid to hired workers and what was spent on the 'Free Africans' under the Government's tutelage system, it is necessary to identify the total cost to the Brazilian government of the 'Free Africans' in the construction of the RJHC. To that end, from the data presented in Table $3,{ }^{3}$ we are able to calculate the total cost of 'Free Africans' compared to the total amount spent on external hired workers.

\section{$<$ Insert Table 3 here $>$}

Table 3 shows that 154 'Free Africans' who worked in the construction of the RJHC in September of 1839 cost the State 66,120 reis in wages $\left(6^{\text {th }}\right.$ line of the statement $)$. This amount, added to the expenses for the supply of food and their clothing amounts to 924,200 reis $\left(7^{\text {th }}\right.$ line of the statement), together with 33,343 reis $\left(13^{\text {th }}\right.$ line of the statement) for medication, a total of 1,023,463 reis. ${ }^{4}$

From Table 3, we can calculate the total of free workers. The total of workers (573) plus an administrator, a registrar, a surgeon, a male nurse, a collector and a gatekeeper (6) is 579. Subtracting the number of 'Free Africans' (176) and Convicts (266) leaves a total of 137 free workers. Comparing, the amount spent on the management of 154 'Free Africans' of 1,023,463 reis, with the 2,252,380 reis spent on the wages of the 137 free workers, not only supports the view expressed by the Administrator that the costs of the free workers was 50 percent higher than those of 'Free Africans', it suggests that the differential was considerably greater than 50 percent.

\footnotetext{
3 Tables were drawn from archival data, seeking to reproduce in a coherent way what was found.

${ }^{4}$ It is assumed in this calculation that, while the amount presented in Table 3 for the item 'medication' relates to all the RJHC's patients, including prisoners, convicts and 'Free Africans', most of it would have been spent on medication for 'Free Africans'.
} 
From the historical documents, it is clear that the hired workers and the 'Free Africans' performed the same work. Considering that the 'Free Africans' originated from the illegal slave trade, it could be deduced that the monetary difference in salaries attributed to the services provided by the external workers and the 'Free Africans' was related to the ideology that black people should remain in the slave labour regime. Race was, therefore, used to justify different wage payments: as previously discussed, proslavery thinking believed the amount spent should only be what was necessary for their survival and to allow them to work the next day (Faust, 1981; Althusser, 1971). In this ideology, accounting calculations provided the means to confirm adherence to this principle and clarity concerning the amount spent on 'Free Africans' compared to free workers.

The 1841 manifest from the 'Free Africans' and the convicts to the Emperor reveals some of the conditions imposed in pursuing and imposing control:

...while they are enduring these abominable punishments, their wages, which the Nation demanded be paid to them for buying smoke, are suspended...

Last year, an African black woman was severely punished. Needless to say, that the punishment was so severe that the victim's clothes turned into a sort of sieve of the whip, and even in that miserable state, stuck in her 'libambo' (steel collar), she lost her wages, and did not leave the 'libambo' until [much later] ... (BN. Manuscritos (Manuscripts), II - 34, 25, 11).

...the food is also a disgrace, because if these poor bastards' commit even the slightest mistake their pot does not even smell like bacon, and only for the most abominable punishments in the world, and whip cutter, they go to the 'libambo' (steel collar), where they spend 2 to 3 months, and then when those punishments end, they have to walk around with a chain... (BN, Manuscritos [Manuscripts], II-34, 25, 11).

Thus, whenever the 'Free Africans' did not behave in accordance with the rules (ISAs), the RSA punished them. From the report shown in Table 3, it can be seen that the RJHC's construction administrator kept periodic inventories of the number of 'Free Africans' that came in, left, and died. This information is presented to track the locality and condition (Fleischman et al., 2011a; Fleischman et al., 2011b) of the 'Free Africans' and other RJHC's construction expenses. The 'Free Africans' were divided into three groups: 'Free' (working at the RJHC's construction); working at Santa Casa; and those who were deposited (see the column 'Free African'). Of the 155 who were working on the RJHC's construction, one died. At the deposit, there were 10 Africans: three came in, three were distributed, and 10 were restored. Of nine 'Free Africans' working at Santa Casa, one got sick and four had been discharged from the infirmary, so 12 remained in service. The observations also account for the 'Free Africans' in the Deposit, that is, those who were waiting at RJHC to be distributed among other public building sites or institutions. This information was important for the 'Free Africans' Curator, so that he could compile it with the rest of the information coming from private and other public institutions, and send a monthly report to the Ministry of Justice, on the movements of the distributed 'Free Africans' (Anonymous, 2019). The Curator did not report on convicts since only 'Free Africans' were part of the tutelage system.

There were several comparative statements kept by the office for the administration of the RJHC's construction regarding the working hours. Besides the reports created individually for each social category (free workers, 'Free Africans', and slaves), it was possible to find statements containing the total number of workers, their wages, and 
their social categories. Reports on the regulation of the work done by the 'Free Africans' in the RJHC include reports that present the amount paid, the distribution of these workers between the different jobs, such as masonry, bricklaying and carpentry, as well as the number of 'Free Africans' assigned to each job (see ANRJ, Fundo Série Justiça [Justice Series Fund], IJ7-11; Casa de Correção (House of Correction)).

The wages received by 'Free Africans' was 620 reis a month, working 31 days (ANRJ, Fundo Série Justiça [Justice Series Fund], IJ7-20). We can see how insignificant this was when compared with the RJHC's Administrator wages $(100,000$ reis a month) and RJHC's Registrar wages (70,000 reis a month) in September 1838 (ANRJ, Fundo Série Justiça [Justice Series Fund], IJ7-20; administrator’s wages).

Although in slavery regimes there was no need to reward labour with wages (Annisette, 1999), in Brazil, the payment of the 'Free Africans' wages, as stated by the RJHC's Administrator, were "a sort of bonus that they receive according to their efforts (merit), which should be enough for their little needs and pleasures" (ANRJ, Fundo Série Justiça [Justice Series Fund], IJ7-13; Letter of 23 February 1857 and Letter of 27 June 1857). Thus, in accordance with Table 4, the wages of 20 reis (for technical labour) and 10 reis (for those without a technical job) were used as a means of coercion of the 'Free Africans' to work and to remain obedient [Mamigonian (2005); Araújo (2009)].

\section{$<$ Insert Table 4 here $>$}

These wages were considered necessary to have well-educated and well-behaved 'Free Africans' (Althusser, 1971). They were withdrawn when 'Free Africans' did not behave properly. In this way, the wages worked as a form of coercion to keep 'Free Africans' acting in accordance with the slavery ideology.

Furthermore, according to Article 12 of the regulation for the Inspection, Administration and Monitoring of the RJHC's construction, the Administrator had the power to 'impose punishments to those who do not fulfil their duties' (ANRJ, Fundo Série Justiça [Justice Series Fund], IIIJ7-138; Aviso do Ministro ao Inspetor das Obras da Casa [Notice from the Minister to the Inspector of the Works of the House]; Araújo, 2009 , p. 187). In an official document, the administrator highlights his efforts in keeping the required respect and subordination from the 'Free Africans' to his demands (ANRJ, Fundo Série Justiça (Justice Series Fund), IJ7-10; Aviso do Inspetor das obras da Casa de Correção ao Ministro [Notice from the Inspector of the works of the House of Correction to the Minister]; Araújo, 2009, p. 192). In a second official document, the administrator reports that "if (the 'Free Africans') deviate from a certain line of conduct, they would be reprimanded, deprived of certain things or even punished" (ANRJ, Fundo Série Justiça [Justice Series Fund], IJ7-13; Letter of 27 June 1857).

The 'Free Africans' were thus kept as coerced workers under threat of physical punishment and by the collusion between Government agents who ignored their complaints (Mamigonian, 2002). The RJHC was driven by an ideology (it was a place where the 'Free African' could learn a job subject to the norms of slavery society), and also by repression (Althusser, 1971). As revealed in the Manifesto of 1841, this not only took the form of deprivation of wages ('the bonuses') but also deprivation of food and physical punishment. The work system, supported by, for example, the whip, the steel 
collar, the chains of iron tied to the feet and other kinds of punishments, was how a great number of 'Free Africans' and slaves were compelled to follow the administrator's will.

The way the 'Free Africans' were treated in Brazil does not differ very much from the way the apprentices in the British West Indies were treated. According to Tyson et al. (2005), the planters and parliament leaders did not believe that former slaves would work of their own free will. The belief that work should be imposed is based on the view that physical punishment increases work productivity (Nardinelli, 1982). Therefore, to instil a sense of work discipline, the apprentices were subject to physical punishment, the payment of fines and other coercion methods that would force them to work (Tyson et al., 2005).

An example of how accounting was used to support racism, and perhaps the most visible example, is the way the work done at the RJHC was categorized in the control records. As previously observed by Fleischman and Tyson (2000) in the Hawaiian sugar cane plantations, at the RJHC the key point of the categorization was also focused on ethnic groups and occupations. As was confirmed by analysis of the data, productivity was not measured through a calculation of what was produced individually by each 'Free African'. Monthly reports were prepared indicating, for each ethnic group, the number and sex of the workers at the construction of the RJHC. In a statement made for the RJHC workers on September 25th, 1851, we can observe a separation between 'Free Africans' and slaves. Concerning 'Free Africans', the statement divides them according to their jobs; 'ladinos' (Africans born in Brazil), and 'boçaes' (Africans brought from the slave ships); male and female. It also indicates that of the existing 336 'Free Africans', 142 were on duty, 94 were ill, and 100 were off duty (see ANRJ, Fundo Série Justiça [Justice Series Fund], IJ7-11; Mapa de trabalhadores [Map of workers]. Regarding the frequency with which each nationality of 'Free Africans' would work, the following table was prepared by the RJHC administrator:

\section{$<$ Insert Table 5 here $>$}

Table 5 shows that some 'Free Africans' worked every day in October 1837. From this and previous tables, we can see that information on 'Free Africans' in the RJHC was systematized, with comprehensive information maintained on the number of 'Free Africans', their health status, their job functions, days worked, and the amount of wages received. In an official document, the RJHC's administrator highlights that the 'Free Africans' employed in one of the RJHC's work sections, totalling sixty men, had presented themselves ready to work punctually on Sundays and holydays, days when most free workers were excused, and had been performing their duties tolerably (ANRJ, Fundo Série Justiça [Justice Series Fund], IJ7-13; Letter of 23 February 1857). Thus, 'Free Africans' were expected to work on days when other categories of workers were excused.

The English Missionary Morgan Goodwyn believed the words 'Negro' and 'Slave' were homogeneous and convertible, due to the tradition at the time (Wolfe, 2001, p. 877), which is consistent with the way that the 'Free Africans' were treated. Due to their skin colour and the belief that all black people should be treated the same way, the 'Free Africans' were burdened with the same racial inequality that was applied to slaves. The conclusion we draw from this evidence is consistent with this perspective: RJHC's 
administration was racist in the way it treated both 'Free Africans' and slaves working in the construction. The differences in treatment by the various intervening actors in the construction of the RJHC are clear in several aspects ranging from food distribution to penalties for breaking the rules. Unlike the free workers, who were hired to work at RJHC's construction, who received their wages to pay for their personal and family expenses, the wages meant for the 'Free Africans', as mentioned above by the administrator, were merely seen as a small bonus. Furthermore, the value of the free workers' wages and the 'Free Africans', as shown in Table 2, reveals a significant difference between them.

The accounting system allowed for the creation of detailed records on the workers and their salaries at the RJHC's construction. Thus, accounting had a role in the regulation of the RJHC's 'Free Africans' that can be characterized as a system geared towards improving surveillance, discipline and control of its workers. These records included the classification of individuals by their personal characteristics and provided for a comparison between them. The data collection technique, rating, registering information, creating tables and columns put all the workers in a state of submission. The punishment and control system acted according to the records kept by the administrator of the RJHC, who registered the days worked and the wages owed to the 'Free Africans' and the rest of the workers. In summary, the preparation of reports for the internal use of the organization and to assist in the preparation of external reports for the management of the RJHC's 'Free Africans', were examples of the use of accounting techniques in a slavery ideology context.

\section{Conclusion}

The objective of this paper was not to analyse the RJHC's accounting system, but to understand the use of accounting information for the control of 'Free Africans' and its use in a context of slavery ideology. From archival sources, we were able to verify that the accounting information for the control of 'Free Africans' at the construction of the RJHC, worked as an intervention tool, designed to facilitate the use of mechanisms that affected and controlled the individual's organizational life. Accounting thus worked as an enabling technology for the application of a disciplinary regime upon the 'Free Africans' that consequently aligned their treatment to that of a slavery ideology. Thus, accounting assisted in reifying the view that 'Free Africans' should not be seen as free workers, but as belonging to a social category similar to slaves (Rodrigues and Craig, 2018).

From a theoretical perspective, through the RJHC accounting documents we not only observed how accounting can illustrate organizational activities, we identified how ideology can be imposed through its use. In this way, this study adds to the existing literature by demonstrating how accounting information can be used in disciplinary regimes in order to monitor the work performed (Tyson et al., 2004) in a public security institution.

The State spent the minimum to enable the 'Free African' to present himself for work (Althusser, 1971) guaranteeing the reproduction of the labour power and ensuring their subjection to the ruling ideology (Althusser, 1971). The 'Free Africans' were inserted into the culture of that time using the tutelage system, but it discriminated against them and positioned them in way that was consistent with a slavery ideology 
(Hall, 1985). Their race justified their exploitation and degradation (Annisette, 2009; 2017) and was used as a primary measuring calculus in the setting of wages. Thus, this paper extends theory by applying the Marxist and Althusserian concepts of reproduction of labour to the case of 'Free Africans'.

There is little direct evidence on how the records on the number of days worked, the number of Africans assigned by occupational functions, the number of Africans who came in and out, who were ill or who died was used. However, from the 1841 manifest written by the 'Free Africans' and convicts, and through official documents prepared by the RJHC administrator, it is clear that these records helped to compare costs and to show the amount of money that it was necessary to obtain the output of 'Free African' labour (Althusser, 1971). Additionally, the documents show that the RJHC administrator, the 'high priest' of the ruling ideology (Althusser, 1971), had a duty to call to order all of those who deviated from a certain line of conduct. Just like his international counterparts (Nardinelli, 1982), the administrator used punishment and restrictions on 'Free Africans' as a means of keeping order and obtaining the desired level of performance from them. This paper extends theory by showing that the salaries paid to the 'Free Africans' were used as a bonus. They cannot be considered as a minimum wage. They were a form of coercion to keep 'Free Africans' docile and acting in accordance with a slavery ideology, and they were withdrawn when they failed to adhere to what was expected of them.

In this paper, we have shown how accounting information (in its widest sense) was used to manage the work done by 'Free Africans' at the RJHC. Regarding the line of research developed in this paper, we believe that there are several opportunities to widen it to other settings either in the field of accounting being used in support of racist regimes, or in the tracking and monitoring of the actions of 'Free Africans' or of the other workers who worked inside the houses of correction inaugurated in other Brazilian states. Critical accounting researchers can also use the theoretical framework proposed in this paper to understand contemporary phenomena, such as how accounting is used to reify discrimination of race or gender; or, for example, how accounting is used to support the management of the workforce in a contemporary prison.

\section{References}

Althusser, L. (1971), "Ideology and ideological state apparatuses", in Althusser, L. (Ed.), Lenin and philosophy and other essays [Brewster B, Trans.], New Left Books, London, pp. 127-187.

Annisette, M. (1999). Importing accounting: the case of Trinidad and Tobago. Accounting, Business \& Financial History, Vol.9 No 1, pp. 103-133.

Annisette, M. (2009). Race and ethnicity. In J. R. Edwards, \& S. P. Walker (Eds.), Routledge companion to accounting history (pp. 451-469). London: Routledge.

Annisette, M., \& Prasad, A. (2017). Critical accounting research in hyper-racial times. Critical Perspectives on Accounting, Vol.43, pp. 5-19.

Anonymous (2019). Accounting as a tool of State governance: The tutelage system of 'Free Africans' in Brazil between 1818 and 1864. Accounting History, forthcoming.

Araújo, C.E.M. (2009), Cárceres Imperiais: A casa de correção do Rio de Janeiro. Seus detentos, o sistema prisional no século, 1830 - 1861. PhD Thesis, University of 
Campinas, SP, Brazil.

Bale, K. (2007), Ending slavery : how we free today's slaves, University of California Press, CA.

Benston, G.J. (1963), "The Role of the Firm's Accounting System for Motivation”, The Accounting Review, Vol.38 No. 2, pp. 347-354.

Bertin, E. (2009), "Reinvidicações e resistênicas: o não dos africanos livres (São Paulo, Séc, XIX), Afro-Ásia, Vol.40, pp. 105-143.

Bethell, L. (1970), The Abolition of the Brazilian Slave Trade: Britain, Brazil and the Slave Trade Question, 1807-1869, Cambridge University Press, CA.

Blackburn, S. (1988), "The problem of riches: from trade boards to a national minimum wage”, Industrial Relations Journal, Vol 19 No 2, pp. 124-138.

Bryer, R. (2006), "Accounting and control of the labor process", Critical Perspectives on Accounting, Vol. 17 No. 5, pp. 551-598.

Caplan, E.H. (1966), "Behavioral Assumptions of Management Accounting”, The Accounting Review, Vol. 41 No. 3, pp. 496-509.

Carmona, S., Ezzamel, M. and Gutiérrez, F. (1997), "Control and cost accounting practices in the Spanish Royal Tobacco Factory", Accounting, Organizations and Society, Vol. 22 No. 5, pp. 411-446.

Chapman, C. S., Cooper, D. J., and Miller, P. (2009), Accounting, organizations, and institutions: Essays in honour of Anthony Hopwood. Oxford: Oxford University Press.

Chazkel, A. (2009), "Community institutions social life and civic education in the Rio De Janeiro city jail”, Journal of Social History, Vol. 42 No. 3, pp. 697-731.

Codato, A. (2016). O conceito de ideologia no marxismo clássico: uma revisão e um modelo de aplicação. Política \& Sociedade, 15(32), 311-331.

Conrad, R. (1973), "Neither Slave nor Free : The Emancipados of Brazil , 1818-1868", The Hispanic American Historical Review, Vol. 53 No. 1, pp. 50-70.

Faust, G.D. (1981), The ideology of slavery: Proslavery thought in the Antebellum South, 1830-1860, Louisiana State University Press, LA.

Fleischman R.K., and Tyson T.N. (2004) Accounting in service to racism: Monetizing slave property in the antebellum South. Critical Perspectives on Accounting, Vol.15 No 3, pp. 376-399.

Fleischman RK, Oldroyd D and Tyson TN (2004) Monetizing human life: Slave valuations on US and British West Indian plantations. Accounting History, Vol 9 No 2, pp. 35-62.

Fleischman RK, Oldroyd D and Tyson TN (2011a) Plantation accounting and management practices in the US and the British West Indies at the end of their slavery eras. Economic History Review, Vol. 64 No. 3, pp. 765-797.

Fleischman, R.K, Oldroyd, D. and Tyson, T.N (2011b). The efficacy/inefficacy of accounting in controlling labour during the transition from slavery in the United States and British West Indies. Accounting, Auditing \& Accountability Journal, 
Vol. 24 No.6, pp. 751-780.

Fleischman, R.K. and Radcliffe, V.S. (2005), "The roaring nineties: accounting history comes of age", The Accounting Historians Journal, Vol. 32 No. 1, pp. 61-109.

Fleischman, R.K. and Tyson, T.N. (2000), "The interface of race and accounting: the case of Hawaiian sugar plantations, 1835-1920”, Accounting History, Vol. 5 No. 1, pp. 7-32.

Florence, A.B. (2002), O cativeiro e a emancipação: a liberdade dos 'Africanos Livres' no Brasil. PhD Thesis. Federal University of Bahia, Bahia, Brazil.

Foucault, M. (1984), "What is Enlightenment", in The Foucault Reader, ed. Paul Rabinow, New York: Pantheon, pp. 32-50.

Foucault, M. (2001) About the Concept of the "Dangerous Individual" in Nineteenthcentury Legal Psycbialry, in: Essential Works of Michel Foucault, Vol. 3: Power, J. D. Faubion, New York: New Press, pp. 176-200.

Glenn, E. N. (1992). From servitude to service work: Historical continuities in the racial division of paid reproductive labor. Signs: Journal of Women in Culture and Society, 18(1), 1-43.

Hall, S. (1985), "Signification, representation, ideology: Althusser and the poststructuralist debates", Critical Studies in Media Communication, Vol. 2 No. 2, pp. 91-114.

Holloway, T.H. (1993), Policing Rio de Janeiro: Repression and Resistance in a 19thCentury City, Stanford University Press, CA.

Hopper, T. and Macintosh, N. (1993),"Management Accounting as disciplinary practice: the case of ITT under Harold Geneen", Management Accounting Research, Vol. 4, pp. 181-216.

Karasch, M.C. (2000), The slave life in Rio de Janeiro, 1808 - 1850, Princeton University Press, AL.

Koerner, A. (2006), "Punição, Disciplina e Pensamento Penal no Brasil do Século XIX”, Lua Nova, Vol. 68, pp. 205-242.

Lake, M. (2014), “Challenging the 'Slave-Driving Employers': Understanding Victoria's 1896 Minimum Wage through a World-History Approach", Australian Historical Studies, Vol. 45 No 1, pp. 87-102.

Lehman, C.R. (2016), "Unshackling Accounting in Prisons: Race, Gender, and Class", in Lehman, C. R. (Ed.) Accounting in Conflict: Globalization, Gender, Race and Class (Advances in Public Interest Accounting, Volume 19). Emerald Group Publishing Limited, pp. $89-112$.

Macintosh, N.B. and Quattrone, P. (2010), Management Accounting and Control Systems: An Organizational and Sociological Approach, John Wiley \& Sons, USA.

Mamigonian, B.G. (2002), To be a liberated African in Brazil: labor and citizenship in the nineteenth century. $\mathrm{PhD}$ Thesis. University of Waterloo, Canadá.

Mamigonian, B.G. (2005), "Revisitando a transição para o trabalho livre: a experiência dos Africanos Livres". in Florentino, M. (Ed.), Tráfico, Cativeiro e Liberdade (Rio de Janeiro, séculos XVII-XIX). Civilização Brasileira, Rio de Janeiro, pp. 389-417.

Mamigonian, B.G. (2017), Africanos Livres na confluência de várias histórias, 
Companhia das Letras, São Paulo.

Marx, K. and Engels, F. (1969), Selected works. Vol. 1. Moscow: Progress.

Marx, K. and Engels, F. (1970), The German Ideology. Vol. 1. International Publishers Co.

Marx, K. (1971), Wage Labor and Capital. New York: International Publishers.

Miller, P. and O' Leary, T. (1987), “Accounting and the construction of the governable person”, Accounting, Organizations and Society, Vol. 12 No. 3, pp. 267-272.

Moreira, A.S. (2005), Liberdade tutelada: Os 'Africanos Livres' e as relações de trabalho na Fábrica de pólvora de Estrela, Serra da Estrela/RJ. 1831-1870. Master Thesis. State University of Campinas, São Paulo, Brazil.

Nardinelli. C. (1982), "Corporal Punishment and Children's Wages in Nineteenth Century Britain”, Explorations in Economics History, Vol. 19, pp. 283-295.

Norrie, A.W. (1991), Law, Ideology and Punishment: Retrieval and Critique of the Liberal Ideal of Criminal Justice, Kluwer Academic Publishers, London.

Praciano, E.R.T (2007), O direito de punir na constituição de 1988 e os reflexos na execução da pena privativa de liberdade. Master Thesis, University of Fortaleza, CE, Brazil.

Reis, J. J. (2008) Domingos Sodré, um sacerdote africano: escravidão, liberdade e candomblé na Bahia do século XIX. Companhia das Letras, São Paulo.

Roberts, J. and Scapens, R. (1985), “Accounting systems and systems of accountability - understanding accounting practices in their organisational contexts", Accounting, Organizations and Society, Vol. 10 No. 4, pp. 443-456.

Rodrigues, L. L., \& Craig, R. (2018). The role of government accounting and taxation in the institutionalization of slavery in Brazil. Critical Perspectives on Accounting. Accounting Vol. 57, pp. 21-38.

Rodrigues, L. L., \& Craig, R. (2009). Teachers as servants of state ideology: Sousa and Sales, Portuguese School of Commerce, 1759-1784. Critical Perspectives on accounting, Vol. 20 No.3, pp. 379-398.

Salla, F. (1999), As prisões em São Paulo: 1822-1940. Annablume, São Paulo.

Silva, M.L. (1997). Do império da lei às grades da cidade. EDIPUCRS, Porto Alegre.

Sorj, B., Cardoso, F.H. and Font, M. (2008), Economia e movimentos sociais na América Latina, SciELO - Centro Edelstein, Rio de Janeiro.

Sousa, J.L.P. (1999), Africano Livre ficando livre: trabalho, cotidiano e luta. $\mathrm{PhD}$ Thesis. University of São Paulo, São Paulo, Brazil.

Tyson, T.N. and Fleischman, R.K. (2006), “Accounting for interned japanese-american civilians during world war II: creating incentives and establishing controls for captive workers", Accounting Historians Journal, Vol. 33 No. 1, pp. 167-202.

Tyson, T.N., Fleischman, R.K. and Oldroyd, D. (2004), "Theoretical perspectives on accounting for labor on slave plantations of the USA and British West Indies", Accounting, Auditing \& Accountability Journal, Vol. 17 No. 5, pp.758-778.

Tyson, T. N., \& Oldroyd, D. (2019). Accounting for slavery during the Enlightenment: Contradictions and interpretations. Accounting History, forthcoming.

Tyson, T.N., Oldroyd, D. and Fleischman, R.K. (2005), "Accounting, Coercion and Social Control During Apprenticeship: converting slave workers to wage workers 
in the British West Indies, C. 1834-1838”, Accounting Historians Journal, Vol. 32 No. 2, pp. 201-231.

Wolfe, P. (2001), "Land, Labor and Difference: Elementary Structures of Race". The American Historical Review, Vol. 106 No. 3, pp. 866-905.

\section{Primary Sources}

Arquivo Nacional do Rio de Janeiro (ANRJ) (The National Archive of Rio de Janeiro)

ANRJ, Constituição para o Império do Brasil de 25 de Março de 1824. Fundo Constituição e Emendas Constitucionais.

ANRJ, Fundo Série Justiça. IIIJ7 - 138. Coleção Casa de Correção: Aviso do Ministro ao Inspetor das obras da Casa. (1834 - 1840) Fl. 75 e Fls. 27 - 29.

ANRJ, Fundo Série Justiça. IIIJ7 - 138. Casa de Correção: Aviso do Ministro ao Inspetor das obras da Casa. (1834 - 1840). Fls. 27 - 29. Artigo 12, Fls. 28

ANRJ, Fundo Série Justiça. IJ7-10 - Casa de Correção: Ofícios com Anexos. (1834 1848). Ofício de 10 de Fevereiro de 1841 destinado ao Ministro da Justiça pelo administrador da casa de correção.

ANRJ, Fundo Série Justiça, IJ 7 - 11. Casa de Correção: Ofícios com anexos (18491851). Mapa de trabalhadores da Casa de Correção em 25 de Setembro de 1851.

ANRJ, Fundo Série Justiça. IJ7-13 - Casa de Correção: Ofícios com anexos (18551858). Ofício de 23 de Fevereiro de 1857 dirigido ao Ministro e Secretário do Estado dos Negócios da Justiça, Sr. Conselheiro José Thomaz Nabuco de Araújo.

ANRJ, Fundo Série Justiça. IJ7-13 - Casa de Correção: Ofícios com anexos (18551858). Ofício de 27 de Junho de 1857 dirigido ao Ministro do Império pelo Administrador da Casa de Correção.

ANRJ, Fundo Série Justiça. IJ7-20 - Casa de Correção: Contabilidade (1834-1838). Feria Concedida aos 'Africanos Livres' da casa de correção e que aprendem ofício no mês de Outubro de 1837.

ANRJ, Fundo Série Justiça. IJ7-20 - Casa de Correção: Contabilidade (1834-1838). Feria Concedida aos 'Africanos Livres' da casa de correção e que aprendem ofício no mês de Novembro de 1837.

ANRJ, Fundo Série Justiça. IJ7-20 - Casa de Correção: Contabilidade (1834-1838). Feria Concedida aos 'Africanos Livres' da casa de correção e que aprendem ofício no mês de Setembro de 1838.

ANRJ, Fundo Série Justiça. IJ7-20 - Casa de Correção: Contabilidade (1834-1838). Vencimento do Administrador no mês de Setembro de 1838.

ANRJ, Fundo Série Justiça. IJ7-21 - Casa de Correção: Contabilidade (1839-1840): Folha de féria dos empregados e operários empregados nas obras da casa de correção no mês de Setembro de 1839.

ANRJ, Fundo Série Justiça. IJ7/21 - Casa de Correção: Contabilidade (1839-40): Mapa dos trabalhadores e operários empregados nas obras da casa de correção em Setembro de 1839.

ANRJ, Fundo Série Justiça. IJ7/21 - Casa de Correção: Contabilidade (1849-1851): Distribuição dos Africanos Livres da casa de correção em 8 de Maio de 1851.

Biblioteca Digital da Camara dos Deputados (BDCD) (Digital Library of the Chamber of Deputies) 
BDCD, Decree 6786 July 1850, pp. 31-62. Coleção de Leis do Império do Brasil de 1850, Rio de Janeiro, Typographia Nacional, 1851.

Biblioteca Nacional (BN) (National Library)

BN, Requerimento dos presos sentenciados a serviço da Casa de Correção a Sua Majestade Imperial relatando a insuportável situação a que eram submetidos pelo administrador daquela casa e pedindo providencias que lhes permitissem viver com dignidade (RJ 02/03/1841) 2 docs. 10 folhas. Microfilme. Manuscrito. Notação - II - 34, 25, 11.

Center for Research Libraries (CRL).

CRL, Relatório da Repartição dos Negócios da Justiça, apresentado à Assembleia Geral Legislativa na sessão ordinária de 1834 pelo Ministro e Secretário de Estado Aureliano de Souza e Oliveira Coutinho. Rio de Janeiro: Tipografia Nacional, 1834.

The UK National Archive

Foreign Office Series FO84/286. 
Table 1: Distribution of 'Free Africans' from the House of Correction on May 8th, 1851

\begin{tabular}{|l|l|l|l|l|l|l|l|l|}
\hline $\begin{array}{l}\text { Name of the } \\
\text { ship } \begin{array}{l}\text { Santa } \\
\text { carried 'Free } \\
\text { Africans' }\end{array}\end{array}$ & $\begin{array}{l}\text { School of } \\
\text { medicine }\end{array}$ & $\begin{array}{l}\text { Rio de } \\
\text { Janeiro } \\
\text { Province }\end{array}$ & $\begin{array}{l}\text { Public } \\
\text { works }\end{array}$ & $\begin{array}{l}\text { State of } \\
\text { Mato } \\
\text { Grosso }\end{array}$ & $\begin{array}{l}\text { Public } \\
\text { Archive }\end{array}$ & $\begin{array}{l}\text { Municipal } \\
\text { County }\end{array}$ & $\begin{array}{l}\text { Total } \\
\text { number }\end{array}$ \\
\hline Rolhas & 169 & 4 & 0 & 0 & 0 & 0 & 0 & 173 \\
\hline Golfinhos & 39 & 0 & 0 & 0 & 0 & 0 & 61 & 100 \\
\hline Marambaias & 28 & 0 & 100 & 1 & 1 & 0 & 35 & 165 \\
\hline Urânias & 0 & 0 & 0 & 26 & 39 & 1 & 28 & 94 \\
\hline Gussaman & 53 & 0 & 0 & 0 & 0 & 0 & 0 & 53 \\
\hline & 289 & 4 & 100 & 27 & 40 & 1 & 124 & 585 \\
\hline
\end{tabular}

Source: ANRJ, Série Justiça, IJ7-21

Table 2: Hired workers' Salaries vs 'Free Africans' Salaries in September 1839

\begin{tabular}{|c|c|c|c|c|}
\hline & \multicolumn{2}{|c|}{ Hired workers' Salaries } & \multicolumn{2}{|c|}{ 'Free Africans'' Salaries } \\
\hline & Name & Daily wages & Name & Daily wages \\
\hline \multirow{3}{*}{ 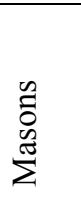 } & Balthazar & 640 & Manoel & 20 \\
\hline & Ambrósio & 640 & Henrique & 20 \\
\hline & Carlos & 640 & Raphael & 20 \\
\hline \multirow{3}{*}{ 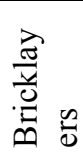 } & Agostinho & 800 & Paulo & 20 \\
\hline & Simão & 800 & Francisco & 20 \\
\hline & João & 800 & Bonifácio & 20 \\
\hline \multirow{3}{*}{ 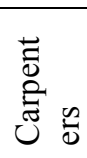 } & Manoel & 720 & José & 20 \\
\hline & Domingos & 720 & André & 20 \\
\hline & João & 720 & Domingos & 20 \\
\hline \multirow{3}{*}{ 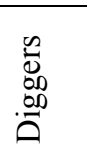 } & Paulo & 480 & Mathias & 20 \\
\hline & João & 480 & Antonio & 20 \\
\hline & Ditto & 480 & Gregorio & 20 \\
\hline
\end{tabular}

Source: Adapted from ANRJ, Série Justiça, IJ7-21 
Table 3: Map of workers and hired workers of the construction of the RJHC in September 1839

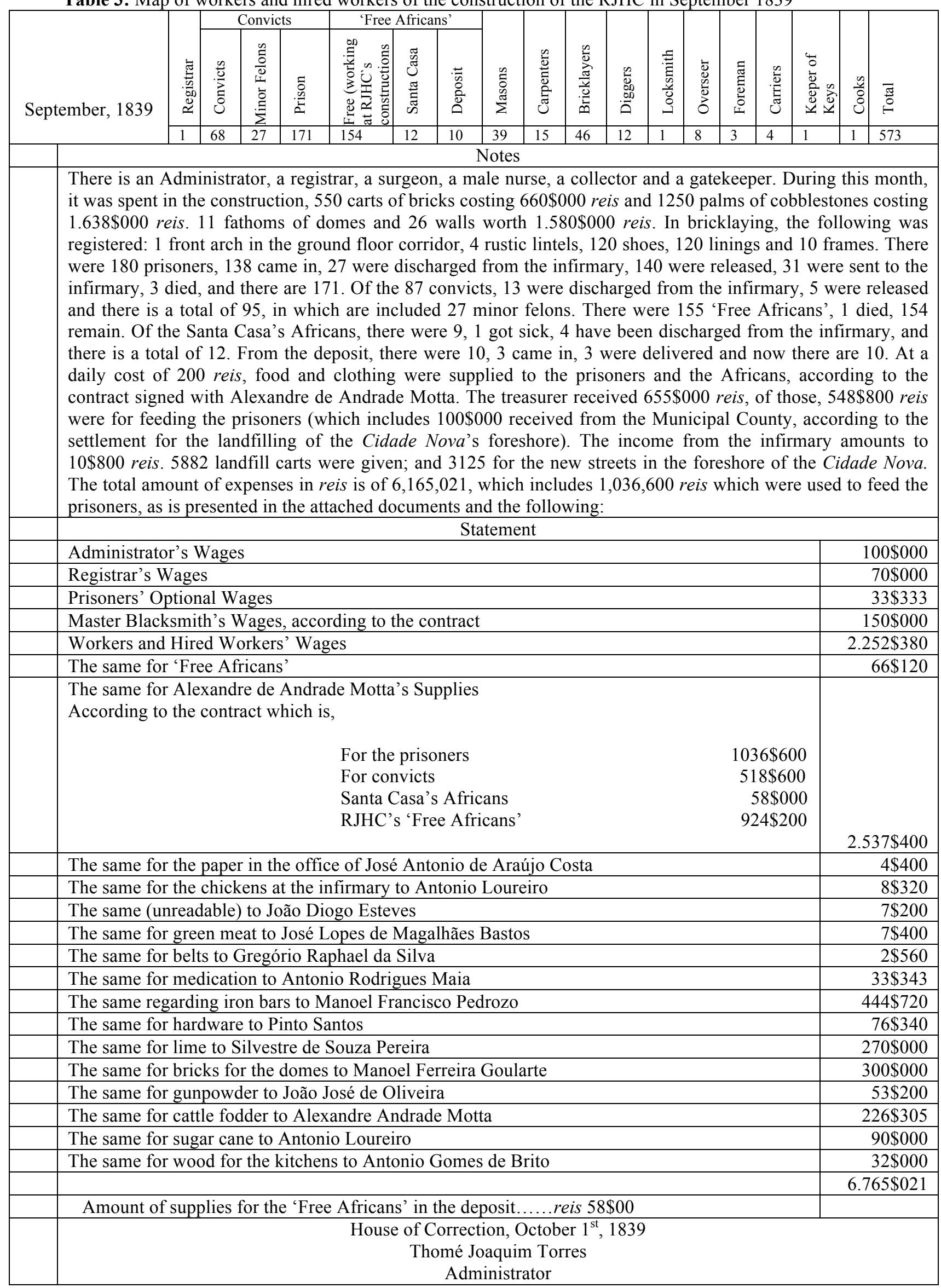

Source: ANRJ, House of Correction's collection, Série Justiça, IJ7-21 
Table 4: Wages paid to 'Free Africans' in November 1837

\begin{tabular}{|c|c|c|}
\hline \multirow[t]{2}{*}{ Classes } & \multicolumn{2}{|c|}{ Wages paid to 'Free Africans' } \\
\hline & Name & Daily Wage \\
\hline \multirow{3}{*}{ 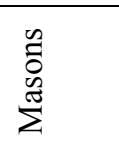 } & Manoel & 20 \\
\hline & Henrique & 20 \\
\hline & Jacinto & 20 \\
\hline \multirow{3}{*}{ 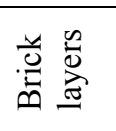 } & Manoel & 20 \\
\hline & Paulo & 20 \\
\hline & Antonio & 20 \\
\hline \multirow{3}{*}{ 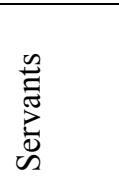 } & Inácio & 10 \\
\hline & Luiz & 10 \\
\hline & Francisco & 10 \\
\hline
\end{tabular}

Source: Adapted from ANRJ, Série Justiça, IJ7-20

Table 5: Wages paid to 'Free Africans' at the Correction House and who learned a job in the month of October 1837

\begin{tabular}{|c|c|c|c|c|c|}
\hline Classes & Names & Nation & $\begin{array}{l}\text { Total number of } \\
\text { Days worked }\end{array}$ & Daily wages & $\begin{array}{c}\text { Monthly } \\
\text { Wages }\end{array}$ \\
\hline \multirow{3}{*}{$\sum_{n}^{\tilde{\Xi}}$} & Manoel & Benguela & 31 & 20 & 620 \\
\hline & Joaquim & Congo & 31 & 20 & 620 \\
\hline & Venâncio & Congo & 7 & 20 & 140 \\
\hline \multirow[b]{2}{*}{ 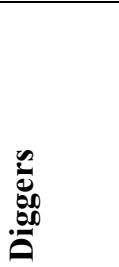 } & Bonifácio & Angola & 31 & 20 & 620 \\
\hline & Paulo & Benguela & 14 & 20 & 280 \\
\hline \multirow{4}{*}{ 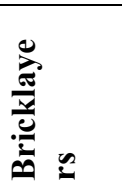 } & Manoel & Angola & 31 & 20 & 620 \\
\hline & Francisco & Angola & 4 & 20 & 80 \\
\hline & Felipe & Cabinda & 31 & 20 & 620 \\
\hline & Constâncio & Congo & 31 & 20 & 620 \\
\hline
\end{tabular}

Source: Adapted from ANRJ, Série Justiça, IJ7-20 